Pure Appl. Chem., Vol. 82, No. 8, pp. 1701-1717, 2010.

doi:10.1351/PAC-CON-09-09-30

(c) 2010 IUPAC, Publication date (Web): 4 June 2010

\title{
On the formation of uranium(V) species in alkali chloride melts*
}

\author{
Vladimir A. Volkovich ${ }^{1, \ddagger}$, Denis E. Aleksandrov ${ }^{1}$, Trevor R. Griffiths ${ }^{2}$, \\ Boris D. Vasin ${ }^{1}$, Timur K. Khabibullin ${ }^{1}$, and Dmitri S. Maltsev ${ }^{1}$ \\ ${ }^{1}$ Department of Rare Metals and Nanomaterials, Ural State Technical \\ University—UPI, Ekaterinburg, 620002, Russia; ${ }^{2}$ Redston Trevor Consulting Ltd., \\ Leeds, LS17 8RF, UK
}

\begin{abstract}
Uranyl(V) species are normally unstable in solutions but are here shown to be stable in high-temperature chloride melts. Reactions leading to the formation of $\mathrm{UO}_{2} \mathrm{Cl}_{4}{ }^{3-}$ ions were studied, including thermal decomposition and chemical reduction of uranyl(VI) chlorospecies in various alkali chloride melts $(\mathrm{LiCl}, 3 \mathrm{LiCl}-2 \mathrm{KCl}, \mathrm{NaCl}-\mathrm{KCl}$, and $\mathrm{NaCl}-2 \mathrm{CsCl})$ at $550-850{ }^{\circ} \mathrm{C}$. Decomposition of $\mathrm{UO}_{2} \mathrm{Cl}_{4}{ }^{2-}$ species under reduced pressure, with inert gas bubbling through the melt or using zirconium getter in the atmosphere results in the formation of $\mathrm{UO}_{2} \mathrm{Cl}_{4}{ }^{3-}$ and $\mathrm{UO}_{2}$. Elemental tellurium, palladium, silver, molybdenum, niobium, zirconium, and hydrogen, as well as niobium and zirconium ions were tested as the reducing agents. The outcome of the reaction depends on the reductant used and its electrochemical properties: uranyl(VI) species can be reduced to uranyl(V) and uranium(IV) ions, and to uranium dioxide.
\end{abstract}

Keywords: molten salts; reduction; spectroscopy; uranium; uranyl.

\section{INTRODUCTION}

Uranium $(\mathrm{V})$ is the least studied of all oxidation states of uranium in solutions. Aqueous solutions of $\mathrm{UO}_{2}{ }^{+}$are prone to disproportionation, and the 5+ oxidation state of uranium has a very narrow range of existence in this medium [1], with the carbonate complex $\mathrm{UO}_{2}\left(\mathrm{CO}_{3}\right)_{3}{ }^{5-}$ being the most stable species [2]. Several U(V) complexes have been characterized in organic solvents [3] and uranium(V) species are stable in ionic solvents. The electronic absorption spectra of uranyl(V) chloro-complexes in chloride melts were reported nearly half a century ago [4,5]. Electrochemical and thermodynamic [6], and structural [7] studies of $\mathrm{UO}_{2}{ }^{+}$in high-temperature chloride melts have subsequently been performed, and the behavior of uranium(V) in low-temperature melts has also been considered [8].

Pentavalent uranium in high-temperature melts exists in the form of complexes of oxo-cations. Investigations concerning uranium( $(\mathrm{V})$ in molten salts have mostly been limited to studying the behavior and properties of the compounds formed rather than the reactions leading to their formation, with the exception perhaps of thermal decomposition and electrochemical reduction of $\mathrm{U}(\mathrm{VI})$. At elevated temperatures, uranyl(VI) chloride decomposes losing $\mathrm{Cl}_{2}$. Such reaction also takes place in chloride melts but there is no agreed opinion concerning products of such decomposition. Wilks [9] reported that during the decomposition of uranyl(VI) chloride dissolved in a chloride melt $\mathrm{Cl}_{2}$ is evolved and $\mathrm{U}_{3} \mathrm{O}_{8}$

\footnotetext{
*Paper based on a presentation on the "Synthesis and Mechanism" theme at the 42 ${ }^{\text {nd }}$ IUPAC Congress, 2-7 August 2009, Glasgow, UK. Other Congress presentations are published in this issue, pp. 1569-1717.

¥Corresponding author
} 
is precipitated. According to Wenz and Adams [4], uranyl(V) ions are formed in the melt below $750{ }^{\circ} \mathrm{C}$ : at higher temperatures $\mathrm{UO}_{2}$ is precipitated and a small amount of $\mathrm{U}(\mathrm{IV})$ ions is formed in the melt. Adams [5] and Stromatt [10] attributed the formation of $\mathrm{UO}_{2}{ }^{+}$ions in the melt to the reaction between $\mathrm{UO}_{2}{ }^{2+}$ and uranium dioxide. Somewhat later, Smirnov et al. [11] reported that upon removing $\mathrm{Cl}_{2}$ from the atmosphere above a uranyl(VI)-containing melt, $\mathrm{U}_{3} \mathrm{O}_{8}$ and uranium tetrachloride are formed.

Electrochemical reduction of $\mathrm{UO}_{2} \mathrm{Cl}_{4}{ }^{2-}$ to $\mathrm{UO}_{2}$ proceeds stepwise via $\mathrm{U}(\mathrm{V})$ as intermediate. Nagai et al. [12] employed high-temperature spectroscopy to study the potentiostatic reduction of $\mathrm{UO}_{2} \mathrm{Cl}_{4}{ }^{2-}$ to $\mathrm{UO}_{2} \mathrm{Cl}_{4}{ }^{3-}$ in a $\mathrm{NaCl}-2 \mathrm{CsCl}$ melt at $650{ }^{\circ} \mathrm{C}$.

$\mathrm{U}(\mathrm{V})$ species in melts can be produced by reducing $\mathrm{U}(\mathrm{VI})$ or oxidizing a lower oxidation state of uranium. Previously [13], we investigated the reaction of uranium dioxide with hydrogen chloride in a series of alkali chloride melts and found that under certain conditions (depending on temperature and cationic melt composition) the reactions led to the oxidation of $\mathrm{UO}_{2}$ to form soluble uranium(V) species, $\mathrm{UO}_{2} \mathrm{Cl}_{4}{ }^{3-}$. The present work was aimed toward studying the chemical reduction and decomposition of uranyl(VI) species in molten alkali metal chlorides.

\section{EXPERIMENTAL}

Experiments were performed in melts based on $\mathrm{LiCl}, \mathrm{NaCl}-\mathrm{KCl}$ equimolar mixture, and 3 $\mathrm{LiCl}-2 \mathrm{KCl}$ and $\mathrm{NaCl}-2 \mathrm{CsCl}$ eutectics at temperatures between 550 and $850{ }^{\circ} \mathrm{C}$. Starting alkali metal chlorides (of analytical purity) were dried at $300^{\circ} \mathrm{C}$ under vacuum for several hours, after which the temperature was raised to ca. $100^{\circ}$ above the melting point and the molten salts were kept under vacuum for $4-5 \mathrm{~h}$ before cooling. These dried salts were subsequently melted, and dry hydrogen chloride was bubbled through them for $5 \mathrm{~h}$ to convert any oxide impurities present into chlorides. Salt mixtures having the required composition were prepared by mixing together the individual alkali chlorides and then fusing them under vacuum. Prior to experimentation, all salt mixtures were subjected to zone refining 5-8 times under vacuum.

Electronic absorption spectra were recorded using a custom-built set-up based on a double-channel fiber optic spectrometer Avantes AvaSpec-2048-2 and a single-channel AvaSpec-NIR256-1.7 that together allowed measurement of spectra between 210 and $1350 \mathrm{~nm}$. Melts (normally 6-10 $\mathrm{ml}$ ) were held in 1-cm path-length optical silica cells attached to silica tubes with side-arms and stoppers containing the necessary electrodes and attachments. Electrochemical measurements were performed employing an Autolab PGSTAT302N potentiostat/galvanostat. All electrode potentials were measured vs. $\mathrm{Ag} / \mathrm{AgCl}(1 \mathrm{~mol} \%$ in $\mathrm{NaCl}-2 \mathrm{CsCl})$ reference electrode. The standard silver potential (relative to $\mathrm{Cl}_{2} / \mathrm{Cl}^{-}$reference electrode) in $\mathrm{NaCl}-2 \mathrm{CsCl}$ melt can be calculated from the following equation [14]:

$$
E^{*} \mathrm{Ag}(\mathrm{I}) / \mathrm{Ag}=\left(-1.223+3.2610^{-4} \mathrm{~T}\right) \pm 0.008 \mathrm{~V}
$$

The starting uranyl(VI)-containing melts were prepared by reacting $\mathrm{UO}_{2}$ or $\mathrm{U}_{3} \mathrm{O}_{8}$ with $\mathrm{Cl}_{2}$ in the chosen alkali chloride melts. These concentrated melts (containing around $10 \mathrm{wt} \%$ uranium) were subsequently used for preparing working melts. For spectroscopy measurements, the initial melts were prepared by dissolving a concentrated sample of quenched melt containing $\mathrm{UO}_{2} \mathrm{Cl}_{2}$ in a chosen salt-solvent so that the initial uranium concentration was about $1 \mathrm{wt} \%$.

Elemental molybdenum, silver, palladium, tellurium, zirconium, and niobium (commercially available above $99 \%$ purity) were used as reducing agents. Molybdenum wire ( $2 \mathrm{~mm}$ diameter) was lowered into the uranyl(VI)-containing melt, and the progress of the reaction was followed by both recording the electronic absorption spectra and the electrode potentials using molybdenum and glassy carbon electrodes. A similar procedure was used with silver. Palladium foil attached to a silica capillary was dipped into the melt, and metallic niobium, zirconium, and tellurium were dropped into the melt as pieces of suitable size.

When studying the reaction of uranyl(VI)-containing melts with niobium and zirconium ions, the starting melts were prepared by dissolving zirconium(IV) chloride or niobium(V) chloride in a chosen 
alkali chloride mixture or by anodically dissolving metallic niobium (to obtain melts containing $\mathrm{Nb}$ (III) and (IV) ions). A sample of uranyl(VI)-containing quenched melt was then dropped into niobium- or zirconium-containing melt.

After each experiment, a sample of melt was withdrawn into a silica capillary using a syringe and rapidly quenched. Quenched melts were analyzed for uranium and other metals (if added) content, and an average uranium oxidation state was also estimated from the results of a redox titration [15]. For this, a sample of the melt that was rapidly quenched was dissolved in a known excess of ammonium vanadate solution (in $5 \mathrm{M}$ sulfuric acid) that oxidized all uranium to $\mathrm{U}(\mathrm{VI})$. The excess of vanadium(V) was then titrated with a solution of iron(II)-ammonium sulfate (also in $5 \mathrm{M} \mathrm{H}_{2} \mathrm{SO}_{4}$ ) and the average oxidation state of uranium in the sample calculated using the following expression:

$$
n(\mathrm{U})=6-\left[\left(C_{\mathrm{V}} \cdot V_{\mathrm{V}}-C_{\mathrm{Fe}} \cdot V_{\mathrm{Fe}}\right) \cdot M_{\mathrm{U}}\right] /\left[m \cdot C_{\mathrm{U}}\right]
$$

where $n(\mathrm{U})$ is the average uranium oxidation state; $C_{\mathrm{V}}$ and $C_{\mathrm{Fe}}$ are the molar concentrations of ammonium vanadate and iron(II)-ammnium sulfate solutions, respectively; $V_{\mathrm{V}}$ and $V_{\mathrm{Fe}}$ are the volumes of ammonium vanadate and iron(II)-ammnium sulfate solutions, respectively; $M_{\mathrm{U}}$ is the molar weight of uranium; $m$ is the weight of the melt sample; and $C_{\mathrm{U}}$ is the weight fraction of uranium in the melt. The effect of additional metals on the results of redox analysis was corrected using the known content and oxidation state determined from spectroscopy measurements (e.g., molybdenum was assumed to be present in the as $\mathrm{MoCl}_{6}{ }^{3-}$ ). IR spectra of quenched melt samples were measured on a Vertex 70 spectrometer (Bruker).

\section{RESULTS AND DISCUSSION}

\section{Decomposition of uranyl(VI) chloride}

Based on literature reports [4,5,9-11], the following reactions, describing the thermal decomposition of uranyl(VI) chloride dissolved in a chloride melt, can be proposed:

$$
\begin{aligned}
& \mathrm{UO}_{2} \mathrm{Cl}_{4}{ }^{2-} \rightarrow \mathrm{UO}_{2}+\mathrm{Cl}_{2}+2 \mathrm{Cl}^{-} \\
& \mathrm{UO}_{2} \mathrm{Cl}_{4}{ }^{2-}+\mathrm{Cl}^{-} \rightarrow \mathrm{UO}_{2} \mathrm{Cl}_{4}{ }^{3-}+1 / 2 \mathrm{Cl}_{2} \\
& 4 \mathrm{UO}_{2} \mathrm{Cl}_{4}{ }^{2-} \rightarrow \mathrm{U}_{3} \mathrm{O}_{8}+\mathrm{UCl}_{6}{ }^{2-}+6 \mathrm{Cl}^{-}+2 \mathrm{Cl}_{2}
\end{aligned}
$$

The main discrepancy in the literature data [4,5,9-11] concerns the possibility of the formation of uranium(IV) ions as a product of decomposition of uranyl(VI) chloride. Absorption spectroscopy offers a convenient way for identifying uranium ions in different oxidation states.

The thermal decomposition of $\mathrm{UO}_{2} \mathrm{Cl}_{4}{ }^{2-}$ species under vacuum $\left(5 \cdot 10^{-3} \mathrm{~mm} \mathrm{Hg}\right)$ was followed here by in situ spectroscopy measurements at $550-850{ }^{\circ} \mathrm{C}$ in $3 \mathrm{LiCl}-2 \mathrm{KCl}, \mathrm{NaCl}-\mathrm{KCl}$, and $\mathrm{NaCl}-2 \mathrm{CsCl}$ melts. During prolonged evacuation at higher temperatures, some solvent salt was sublimed, particularly with the cesium-containing melt, e.g., at $850^{\circ} \mathrm{C}$ after $40 \mathrm{~min}$ the volume of the melt was reduced almost by half with sublimed salt condensed in the upper cold part of the cell.

In the course of the experiments, the yellow color of the initial uranyl(VI)-containing melts changed to brown and the absorbance in the visible region increased. The behavior in all the melts studied was similar. All spectra contained a broad band at around $770 \mathrm{~nm}$, typical of $\mathrm{UO}_{2} \mathrm{Cl}_{4}{ }^{3-}$ absorption in chloride melts [4,5] and arising from a $\varphi_{5 \mathrm{u}} \rightarrow 3 \pi_{1 \mathrm{u}}$ transition [16]. A second band at around $620 \mathrm{~nm}$ $\left(\varphi_{5 \mathrm{u}} \rightarrow 3 \pi_{3 \mathrm{u}}\right.$ transition [16]) was hidden under a low-energy edge of a charge-transfer band. An example of the spectra recorded in $\mathrm{NaCl}-\mathrm{KCl}$ melt is given in Fig. 1, and the results of the experiments conducted are summarized in Table 1. No absorption bands that could be attributed to U(IV) chloro-ions were observed. 

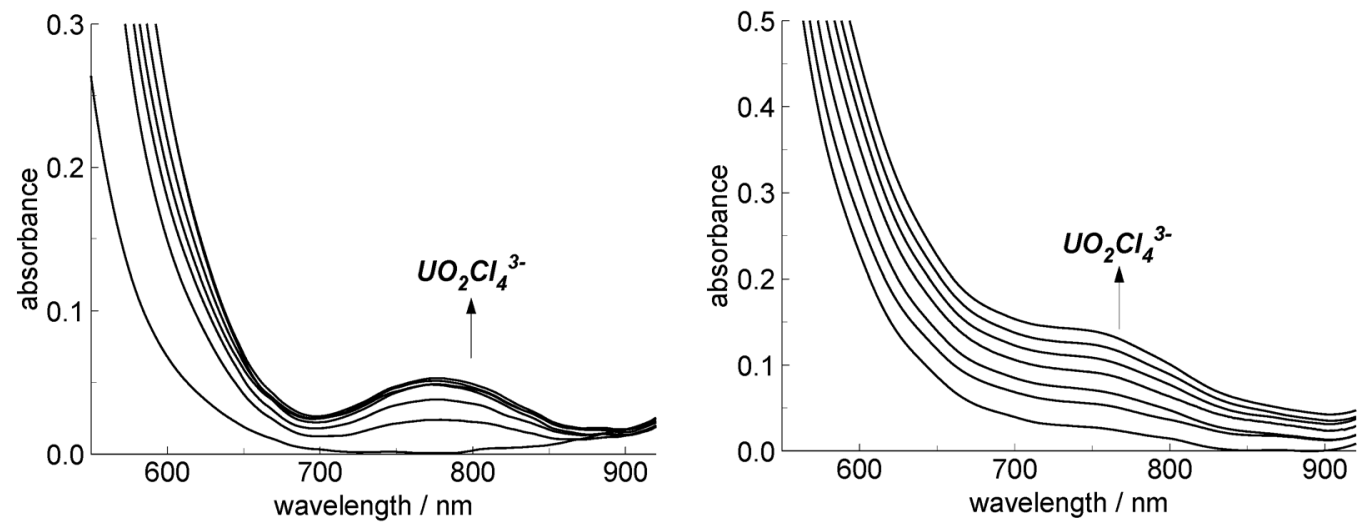

Fig. 1 Changes in the spectra of $\mathrm{NaCl}-\mathrm{KCl}$ melt containing $\mathrm{UO}_{2} \mathrm{Cl}_{4}{ }^{2-}$ species and held under vacuum at $750{ }^{\circ} \mathrm{C}$ for $240 \mathrm{~min}$ (left) and at $850{ }^{\circ} \mathrm{C}$ for $206 \mathrm{~min}$ (right). Initial uranium concentration was around $0.9 \mathrm{wt} \%$. Arrows indicate spectral changes with time.

Table 1 Decomposition of uranyl(VI) chloro-species in alkali chloride melts under vacuum.

\begin{tabular}{lccccc}
\hline Melt & $T,{ }^{\circ} \mathrm{C}$ & $\begin{array}{c}\text { Time held under } \\
\text { vacuum, min }\end{array}$ & \multicolumn{2}{c}{ U conc., wt \% } & \multicolumn{2}{c}{$\begin{array}{c}\text { Final U } \\
\text { initial }\end{array}$} & final & oxidation state \\
\hline $3 \mathrm{LiCl}-2 \mathrm{KCl}$ & 550 & 340 & 0.76 & 0.53 & 5.7 \\
& 750 & 265 & 0.90 & 0.67 & 5.7 \\
$\mathrm{NaCl}-\mathrm{KCl}$ & 750 & 240 & 0.96 & 0.78 & 5.8 \\
& 850 & 206 & 0.86 & 0.79 & 5.7 \\
$\mathrm{NaCl}-2 \mathrm{CsCl}$ & 650 & 92 & 0.29 & 0.26 & 5.7 \\
& 650 & 150 & 1.15 & 1.22 & 5.9 \\
& 750 & 173 & 1.13 & $1.59^{\mathrm{a}}$ & 5.9 \\
& 850 & 40 & 1.18 & $2.00^{\mathrm{a}}$ & 5.3 \\
\hline
\end{tabular}

${ }^{a}$ Volume of the melt was significantly reduced due to solvent-salt sublimation.

Increasing the temperature resulted in a somewhat more rapid rate of decomposition. IR spectra of quenched melt samples after thermal decomposition contained bands due to U-O stretching in uranyl(VI) and uranyl(V) groups, Fig. 2. It can be noted that some uranyl(V) disproportionation (to uranyl(VI) and $\mathrm{UO}_{2}$ ) could occur upon quenching the liquid melt, especially from higher temperatures. The results in Fig. 2, however, show that the intensity of uranyl(V) band was growing with temperature, thus showing that uranium(V) content in the liquid melt was higher at elevated temperature.

Cationic melt composition had a more pronounced effect: at $750{ }^{\circ} \mathrm{C}$ the rate of decomposition was highest in the $3 \mathrm{LiCl}-2 \mathrm{KCl}$ eutectic and lowest in the $\mathrm{NaCl}-2 \mathrm{CsCl}$ eutectic, with the $\mathrm{NaCl}-\mathrm{KCl}$ equimolar mixture occupying an intermediate position. Smaller alkali metal cations have a greater destabilizing effect on $\mathrm{UO}_{2} \mathrm{Cl}_{4}{ }^{2-}$ ions, and the stability of uranyl(VI) complex in chloride melts therefore decreases upon changing the melt cation from $\mathrm{Cs}^{+}$to $\mathrm{Li}^{+}$.

Another method of $\mathrm{Cl}_{2}$ removal from the experimental cell was sparging the melt with argon. Bubbling pure Ar gas through $\mathrm{NaCl}-2 \mathrm{CsCl}-\mathrm{UO}_{2} \mathrm{Cl}_{2}$ melt resulted in sweeping the $\mathrm{Cl}_{2}$ formed from the atmosphere above the melt as well as assisting conversion of $\mathrm{UO}_{2} \mathrm{Cl}_{4}{ }^{2-}$ into $\mathrm{UO}_{2} \mathrm{Cl}_{4}{ }^{3-}$. The presence of $\mathrm{O}_{2}$ /air impurities in argon, however, leads to the formation of insoluble alkali metal uranates. 


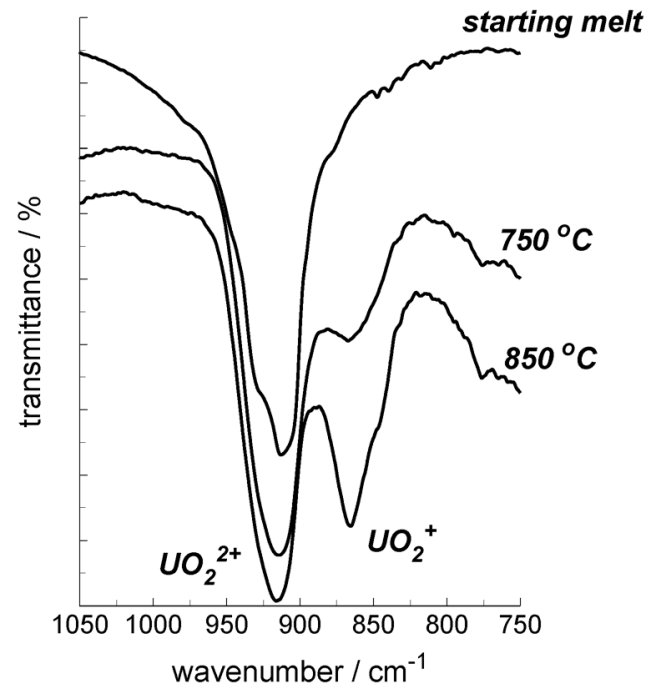

Fig. 2 IR spectra of quenched $\mathrm{NaCl}-\mathrm{KCl}$-based melts containing $\mathrm{UO}_{2} \mathrm{Cl}_{2}$ before and after heating under vacuum.

Thermodynamic calculations show that the equilibrium $\mathrm{Cl}_{2}$ pressure above alkali chloride melts containing $\mathrm{UO}_{2} \mathrm{Cl}_{4}{ }^{2-}, \mathrm{UO}_{2} \mathrm{Cl}_{4}{ }^{3-}$, and $\mathrm{UO}_{2}$ is below $10^{-5} \mathrm{~mm} \mathrm{Hg}$ (such low pressure could not be achieved with the vacuum system employed in the present study). To lower chlorine pressure in the atmosphere in the experimental cell, a zirconium metal getter was positioned $15 \mathrm{~mm}$ above the melt surface. At working temperatures, zirconium easily reacts with chlorine and the equilibrium pressure of $\mathrm{Cl}_{2}$ in the presence of $\mathrm{Zr}$ metal is below $10^{-10} \mathrm{~mm} \mathrm{Hg}$. The experiments were conducted between 550 and $750{ }^{\circ} \mathrm{C}$ in several melts, and the results are summarized in Table 2. During the reaction, uranyl(V) ions, $\mathrm{UO}_{2} \mathrm{Cl}_{4}{ }^{3-}$, and some uranium dioxide were formed in the melt and a black compound (most likely a low-oxidation-state zirconium chloride) was deposited on the surface of zirconium turnings acting as a getter. An example of the spectra recorded is presented in Fig. 3. Final melts contained a mixture of uranyl(V) and (VI) ions; no soluble U(IV) chloro-species were present. Concentration changes of uranyl(V) species were monitored using the absorbance around $780 \mathrm{~nm}$ and preliminary determined $\mathrm{U}(\mathrm{V})$ molar absorption coefficients for the melts and the temperatures employed. The results are presented in Fig. 4. Increasing the temperature resulted in a somewhat higher concentration of uranyl(V) ions. Under similar starting conditions (initial uranyl(VI) concentration and temperature), the concentration of $\mathrm{U}(\mathrm{V})$ ions was higher in the melt with the larger cations, the $\mathrm{NaCl}-2 \mathrm{CsCl}$ eutectic.

Table 2 Decomposition of uranyl(VI) chloro-species in alkali chloride melts with $\mathrm{Zr}$ getter positioned in the atmosphere above the melt.

\begin{tabular}{lccccc}
\hline Melt & $T,{ }^{\circ} \mathrm{C}$ & $\begin{array}{c}\text { Time held under } \\
\text { vacuum, min }\end{array}$ & \multicolumn{2}{c}{ U conc., wt \% } & \multicolumn{2}{c}{$\begin{array}{c}\text { Fraction of U } \\
\text { initial }\end{array}$} & final & remaining in melt, \% \\
\hline $3 \mathrm{LiCl}-2 \mathrm{KCl}$ & 550 & 180 & 0.77 & 0.32 & 62 \\
& 750 & 380 & 0.74 & 0.23 & 23 \\
$\mathrm{NaCl}-\mathrm{KCl}$ & 750 & 336 & 0.78 & 0.32 & 42 \\
& 750 & 410 & 0.81 & 0.34 & 42 \\
$\mathrm{NaCl}-2 \mathrm{CsCl}$ & 550 & 123 & 0.74 & 0.74 & 100 \\
& 650 & 218 & 0.79 & 0.77 & 98 \\
& 650 & 235 & 0.92 & 0.84 & 91 \\
& 750 & 170 & 0.65 & 0.51 & 78 \\
\hline
\end{tabular}




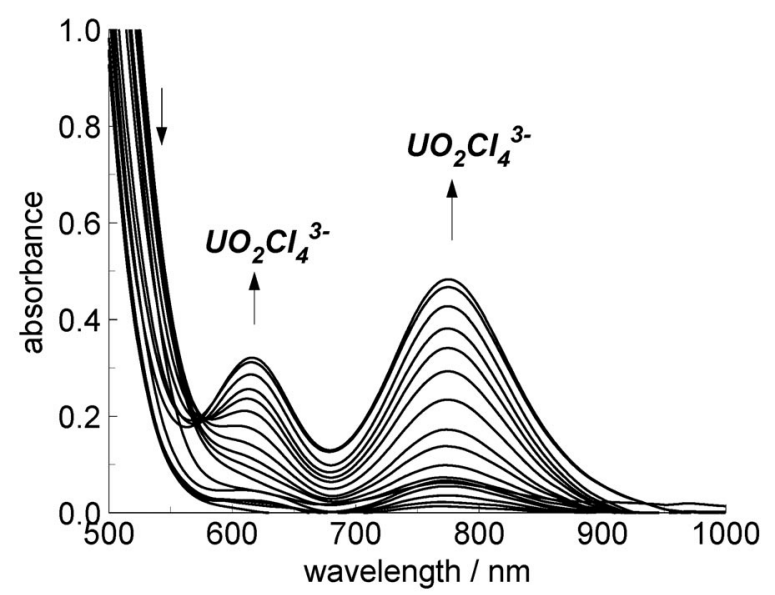

Fig. 3 Changes in the spectra of $\mathrm{NaCl}-2 \mathrm{CsCl}$ melt containing $\mathrm{UO}_{2} \mathrm{Cl}_{4}{ }^{2-}$ with $\mathrm{Zr}$ getter positioned above the melt, $650{ }^{\circ} \mathrm{C}$, total time of reaction $244 \mathrm{~min}$. Arrows indicate spectral changes with time.

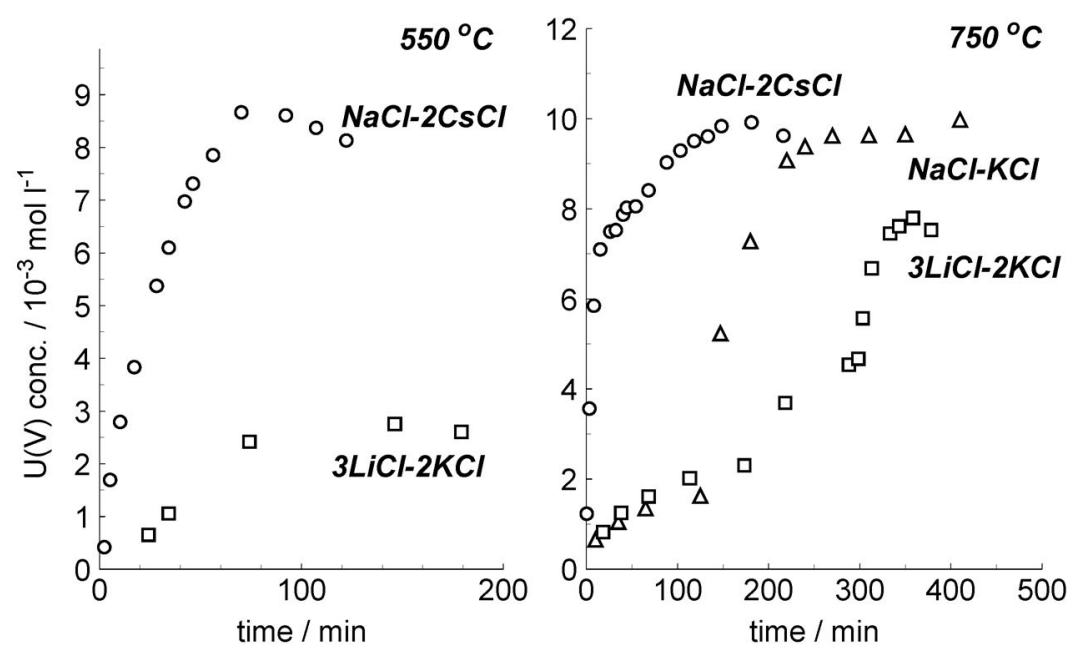

Fig. 4 Changes of $\mathrm{U}(\mathrm{V})$ concentration in chloride melts containing $\mathrm{UO}_{2} \mathrm{Cl}_{2}$ with $\mathrm{Zr}$ getter positioned above the melt.

These experiments thus show that the decomposition of uranyl(VI) chloro-species in alkali chloride melts proceeds according to reactions 3 and 4 and results in the formation of soluble uranyl(V) chloride and insoluble uranium dioxide.

\section{Reaction of uranyl(VI)-containing melts with metals}

The various elements present in spent nuclear fuel or used as construction materials can react with uranyl-containing melts resulting in the reduction of $\mathrm{U}(\mathrm{VI})$ ions. In the present work, a number of elements, representing various groups of fission products, were investigated. These were tellurium, palladium, silver, molybdenum, niobium, and zirconium with tellurium and palladium being the most electropositive amongst these, and niobium and zirconium the most electronegative. The reaction of metallic platinum and molybdenum with uranyl(VI)-containing melts was noted by Smirnov and Skiba [17], but the mechanism was not studied and the products formed were not characterized.

(C) 2010, IUPAC

Pure Appl. Chem., Vol. 82, No. 8, pp. 1701-1717, 2010 


\section{Palladium and tellurium}

The standard redox potential of tellurium in alkali chloride melts is more positive than that of palladium. Elemental tellurium in molten $\mathrm{NaCl}-2 \mathrm{CsCl}$ containing uranyl chloride at $550{ }^{\circ} \mathrm{C}$ reacted slowly. After $3 \mathrm{~h}$ the oxidation state of uranium in the melt had decreased to 5.92 and the absorption spectra contained two well-pronounced bands corresponding to the uranyl(V) complex, $\mathrm{UO}_{2} \mathrm{Cl}_{4}{ }^{3-}$, Fig. 5 . Uranium concentration in this melt decreased from 0.86 to $0.79 \mathrm{wt} \%$. Palladium reacted similarly, but the reaction rate was somewhat faster. After around $3.5 \mathrm{~h}$ of contact with palladium foil, the oxidation state of uranium in the uranyl(VI)-containing melt at $550{ }^{\circ} \mathrm{C}$ decreased from 6 to 5.68 and the spectra contained the absorption bands of $\mathrm{UO}_{2} \mathrm{Cl}_{4}{ }^{3-}$ and $\mathrm{PdCl}_{6}{ }^{4-}$, Fig. 6. Electronic absorption spectra of palladium in fused chlorides were reported in a number of works [18] and in the visible region arise from ${ }^{1} \mathrm{~A}_{1 \mathrm{~g}} \rightarrow{ }^{1} \mathrm{~A}_{2 \mathrm{~g}}$ and ${ }^{1} \mathrm{~A}_{1 \mathrm{~g}} \rightarrow{ }^{1} \mathrm{E}_{\mathrm{g}}$ electronic transitions in tetragonally distorted $\mathrm{PdCl}_{6}{ }^{4-}$ ion. The concen-

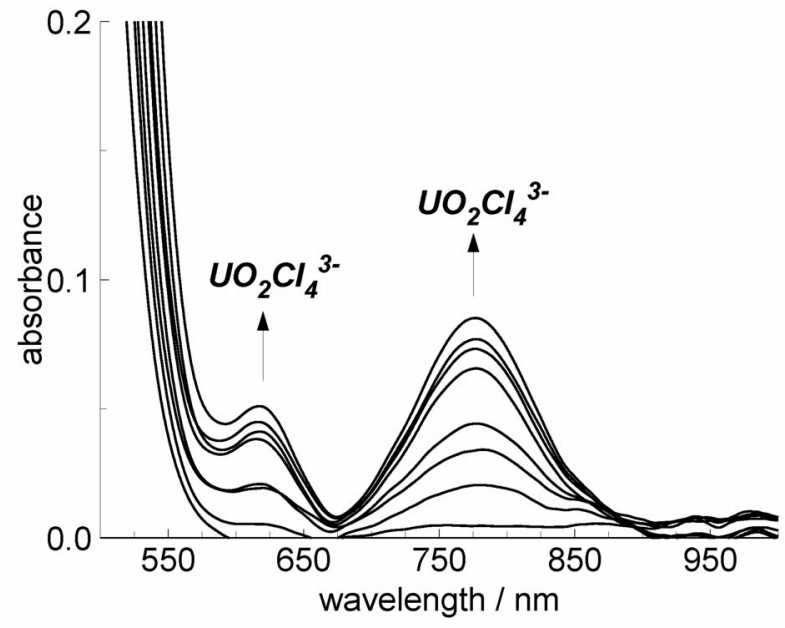

Fig. 5 Spectra showing increasing concentration of $\mathrm{UO}_{2} \mathrm{Cl}_{4}{ }^{3-}$ with time, by the reaction of Te with $\mathrm{UO}_{2} \mathrm{Cl}_{2}$ in the $\mathrm{NaCl}-2 \mathrm{CsCl}$ melt at $550{ }^{\circ} \mathrm{C}$. Total reaction time: $180 \mathrm{~min}$.

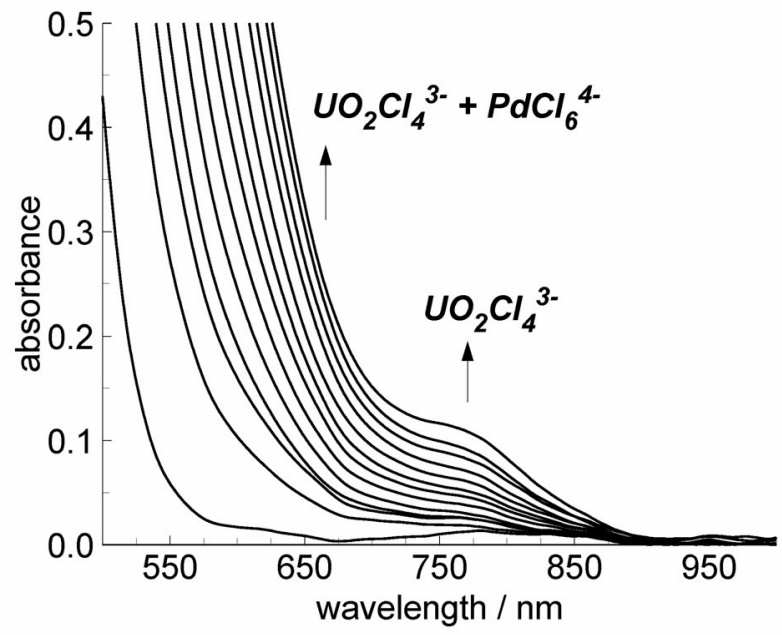

Fig. 6 Spectra showing increasing concentration of $\mathrm{UO}_{2} \mathrm{Cl}_{4}{ }^{3-}$ and $\mathrm{PdCl}_{6}{ }^{4-}$ with time, for the reaction of $\mathrm{Pd}$ with $\mathrm{UO}_{2} \mathrm{Cl}_{2}$ in the $\mathrm{NaCl}-2 \mathrm{CsCl}$ melt at $550{ }^{\circ} \mathrm{C}$. Total reaction time: $216 \mathrm{~min}$. 
tration of uranium remaining in the melt also decreased slightly, from 0.98 to $0.91 \mathrm{wt} \%$, due to $\mathrm{UO}_{2}$ formation and precipitation. Tellurium and palladium therefore mainly reduce $\mathrm{UO}_{2} \mathrm{Cl}_{4}{ }^{2-}$ to $\mathrm{UO}_{2} \mathrm{Cl}_{4}{ }^{3-}$, and to some $\mathrm{UO}_{2}$ :

$$
\begin{aligned}
& 4 \mathrm{UO}_{2} \mathrm{Cl}_{4}{ }^{2-}+\mathrm{Te}+6 \mathrm{Cl}^{-} \rightarrow 4 \mathrm{UO}_{2} \mathrm{Cl}_{4}{ }^{3-}+\mathrm{TeCl}_{6}{ }^{2-} \\
& 2 \mathrm{UO}_{2} \mathrm{Cl}_{4}{ }^{2-}+\mathrm{Pd}+6 \mathrm{Cl}^{-} \rightarrow 2 \mathrm{UO}_{2} \mathrm{Cl}_{4}{ }^{3-}+\mathrm{PdCl}_{6}{ }^{4-}
\end{aligned}
$$

\section{Silver and molybdenum}

Silver is more electronegative than palladium. Immersing silver wire into the $\mathrm{NaCl}-2 \mathrm{CsCl}+\mathrm{UO}_{2} \mathrm{Cl}_{2}$ melt at 550 and $650{ }^{\circ} \mathrm{C}$ resulted in reduction of $\mathrm{U}(\mathrm{VI})$ to $\mathrm{U}(\mathrm{V})$ ions in the melt and solid $\mathrm{UO}_{2}$. At $650{ }^{\circ} \mathrm{C}$, after $243 \mathrm{~min}$, the oxidation state of uranium in the melt had dropped to 5.27 and the concentration of uranium in the melt from 0.95 to $0.11 \mathrm{wt} \%$. Electrode potential measurements (on silver and glassy carbon electrodes) showed that over $4 \mathrm{~h}$ the system had not reached equilibrium.

Molybdenum is electrochemically slightly more active than silver, and the reaction of uranyl(VI)containing melts with Mo was studied in more detail. In NaCl-2CsCl-based melts at 550, 650, and $750{ }^{\circ} \mathrm{C}$, the absorbance in the visible region of the spectra gradually increased and bands corresponding to the absorption of $\mathrm{UO}_{2} \mathrm{Cl}_{4}{ }^{3-}$ and $\mathrm{MoCl}_{6}{ }^{3-}$ arose, Fig. 7. The absorption bands of molybdenum(III) originate from a spin forbidden ${ }^{4} \mathrm{~A}_{2 \mathrm{~g}} \rightarrow{ }^{2} \mathrm{~T}_{2 \mathrm{~g}}$ (around $680 \mathrm{~nm}$ ) and a spin allowed ${ }^{4} \mathrm{~A}_{2 \mathrm{~g}} \rightarrow{ }^{4} \mathrm{~T}_{2 \mathrm{~g}}$ (around $590 \mathrm{~nm})$ transitions [19]. Another spin-allowed transition $\left({ }^{4} \mathrm{~A}_{2 \mathrm{~g}} \rightarrow{ }^{4} \mathrm{~T}_{1 \mathrm{~g}}\right)$ in $\mathrm{MoCl}_{6}{ }^{3-}$ gives an absorption band around $420 \mathrm{~nm}$ that is completely hidden in our case. The reaction in molten $\mathrm{NaCl}-\mathrm{KCl}$ at $750{ }^{\circ} \mathrm{C}$ was similar. In $3 \mathrm{LiCl}-2 \mathrm{KCl}$ and, especially $\mathrm{LiCl}$ melts at $750{ }^{\circ} \mathrm{C}$, the observed picture was rather different. Uranyl(V) concentration in the melt rapidly reached a maximum and then started to decrease.

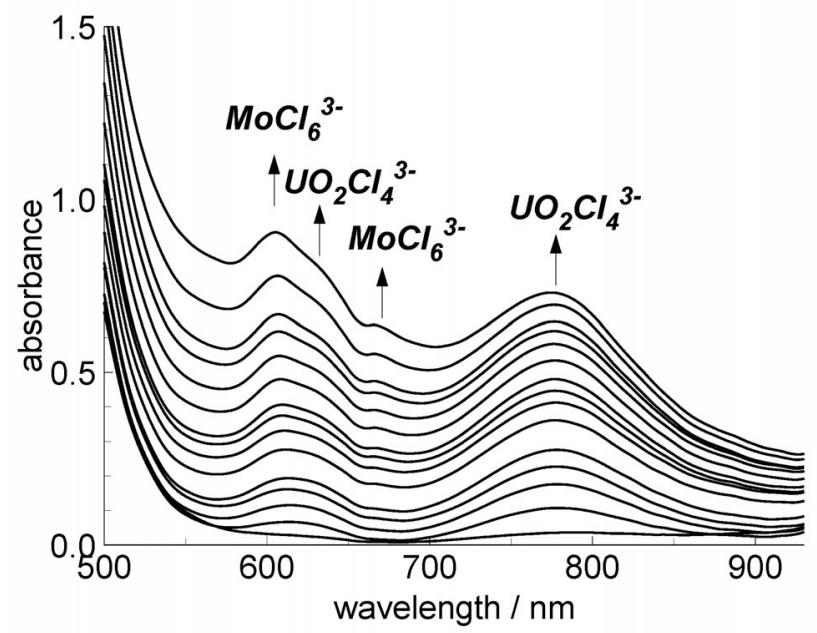

Fig. 7 Spectra recorded during the reaction of Mo metal with $\mathrm{UO}_{2} \mathrm{Cl}_{2}$ dissolved in molten $\mathrm{NaCl}-2 \mathrm{CsCl}$ at $650{ }^{\circ} \mathrm{C}$. Initial U concentration 0.85 wt \%. Total reduction time: 116 min.

The rate at which uranyl(V) concentration changes in the melt can be obtained from these spectra using absorbance values at around $780 \mathrm{~nm}$, where uranyl(VI) and molybdenum(III) ions do not absorb. Uranium $(\mathrm{V})$ concentration was determined from the spectra and the results obtained in the $\mathrm{NaCl}-2 \mathrm{CsCl}$ melt at varied temperatures and at $750{ }^{\circ} \mathrm{C}$ in various melts are shown in Fig. 8.

Increasing the temperature resulted in an increased rate of uranyl(V) formation in the melt, Fig. 8. Increasing the initial uranyl(VI) concentration had the same effect. Increasing the rate of $U(V)$ formation with temperature can have two reasons, increasing the rate of the reduction process and shifting the 

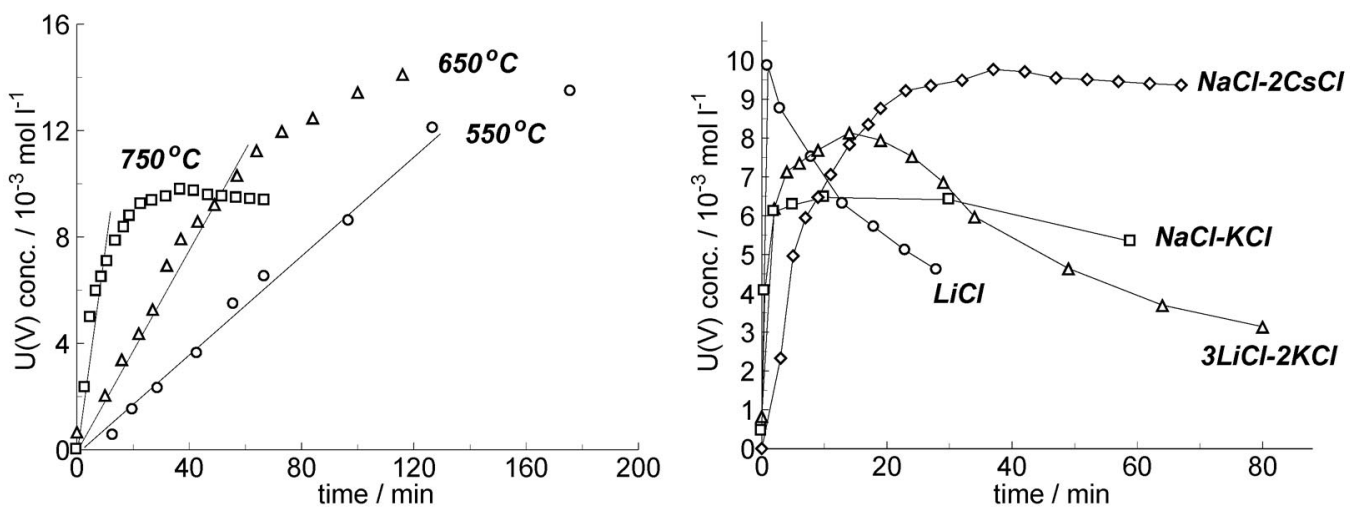

Fig. 8 The effect of temperature (left) on the extent of $\mathrm{U}(\mathrm{V})$ accumulation in molten $\mathrm{NaCl}-2 \mathrm{CsCl}$ and the effect of melt composition (right) on the extent of $\mathrm{U}(\mathrm{V})$ accumulation at $750{ }^{\circ} \mathrm{C}$ in various uranyl(VI)-containing melts during contact with Mo metal. Initial U concentration $0.8-0.9$ wt \%.

electrode potential values for the $\mathrm{UO}_{2}{ }^{2+} / \mathrm{UO}_{2}{ }^{+}$couple. The latter reason, however, is less probable since the difference between the redox potentials of $\mathrm{UO}_{2}{ }^{2+} / \mathrm{UO}_{2}{ }^{+}$and $\mathrm{Mo}^{3+} / \mathrm{Mo}$ couples decreases as the temperature rises, e.g., in $\mathrm{NaCl}-2 \mathrm{CsCl}$ melt at $550{ }^{\circ} \mathrm{C}$ the formal standard potentials of $\mathrm{U}(\mathrm{VI}) / \mathrm{U}(\mathrm{V})$ and $\mathrm{Mo}(\mathrm{III}) / \mathrm{Mo}$ are equal to -0.918 and $-1.015 \mathrm{~V}$ (vs. chlorine reference electrode), respectively, and at $750{ }^{\circ} \mathrm{C}$ they are equal to -0.825 and $-0.842 \mathrm{~V}$, respectively $[6,20]$.

The uranyl(V) concentration reached a maximum and essentially stabilized in $\mathrm{NaCl}-2 \mathrm{CsCl}$-based melts but then slowly decreased in $\mathrm{NaCl}-\mathrm{KCl}$ melts, Fig. 8. In molten $3 \mathrm{LiCl}-2 \mathrm{KCl}, \mathrm{U}(\mathrm{V})$ concentration decreased more rapidly than in $\mathrm{NaCl}-\mathrm{KCl}$ and the time interval at which the $\mathrm{UO}_{2} \mathrm{Cl}_{4}{ }^{3-}$ concentration essentially stabilized was shorter. $\mathrm{In} \mathrm{LiCl}$ melt, the uranyl(V) concentration rapidly reached its maximum and then immediately started dropping. In all the systems investigated, the surface of the molybdenum wire dipped into the melt was afterwards covered with black cubic or octahedral crystals of uranium dioxide.

Electrode potentials were measured on both molybdenum and glassy carbon electrodes during these experiments. In $\mathrm{NaCl}-\mathrm{KCl}$ and $\mathrm{NaCl}-2 \mathrm{CsCl}$ melts after $30-100$ min, depending on the initial uranium concentration in the melt and the temperature, the potential values on the two electrodes became identical, indicating that the system had reached equilibrium, Fig. 9. $\mathrm{In} \mathrm{LiCl}$ and $3 \mathrm{LiCl}-2 \mathrm{KCl}$ melts, the
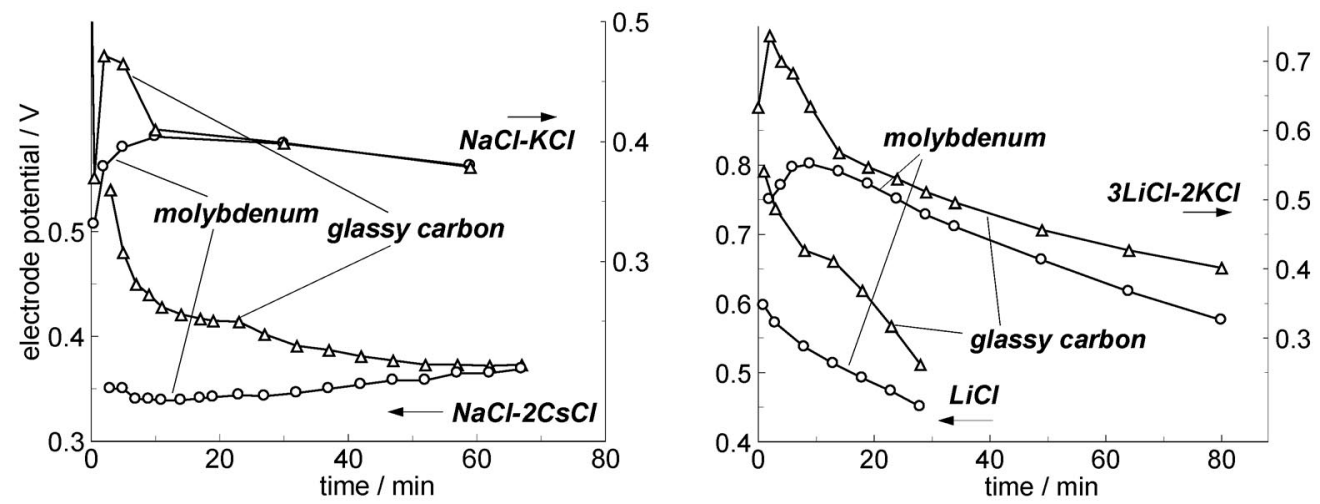

Fig. 9 Changes in electrode potentials at $750{ }^{\circ} \mathrm{C}$ in chloride melts containing $\mathrm{UO}_{2} \mathrm{Cl}_{2}$ during contact with Mo metal. Melt composition is shown for each plot. 
uranium concentration in the melt constantly decreased and the difference between the potentials on molybdenum and glassy carbon electrodes was around 0.05-0.08 V, Fig. 9.

The results of experiments on reducing uranyl(VI) species in alkali chloride melts with metallic molybdenum are summarized in Table 3. Decreasing the starting U(VI) content in the melt led to an increased degree of uranium reduction, e.g., in $\mathrm{NaCl}-2 \mathrm{CsCl}$ melt, the average oxidation state of uranium in the final melt decreased from 5.85 to 5.04 upon lowering the initial uranium concentration from 1.71 to $0.19 \mathrm{wt} \%$. At the same time, the fraction of uranium reduced to $\mathrm{UO}_{2}$ also increased from near a quarter to almost a half. In the same melt, an increase in the temperature at a constant initial U(VI) concentration had a similar effect. Upon going from 550 to $750{ }^{\circ} \mathrm{C}$ the uranium oxidation state in the melt decreased from 5.56 to 5 and the percentage of uranium remaining in the melt from 65 to $21 \%$.

Table 3 Reaction of uranyl(VI)-containing melts with metallic Mo.

\begin{tabular}{lccccccc}
\hline $\begin{array}{l}\text { Melt } \\
\text { composition }\end{array}$ & $T,{ }^{\circ} \mathrm{C}$ & $\begin{array}{c}\text { U(VI) initial } \\
\text { conc., wt. } \%\end{array}$ & $\begin{array}{c}\text { Time, } \\
\text { min }\end{array}$ & $\begin{array}{c}\text { U final } \\
\text { conc., wt } \%\end{array}$ & $\begin{array}{c}\text { Fraction of U } \\
\text { remaining } \\
\text { in melt, } \%\end{array}$ & $\begin{array}{c}\text { Final U } \\
\text { oxidation state }\end{array}$ & $\begin{array}{c}\text { Final Mo } \\
\text { conc., wt } \%\end{array}$ \\
\hline $\mathrm{NaCl}-2 \mathrm{CsCl}$ & 550 & 1.71 & 210 & 1.32 & 77 & 5.85 & 0.024 \\
& 550 & 0.85 & 176 & 0.55 & 65 & 5.56 & 0.029 \\
& 550 & 0.52 & 267 & 0.32 & 62 & 5.44 & 0.016 \\
& 550 & 0.19 & 204 & 0.10 & 52 & 5.04 & 0.012 \\
& 650 & 0.85 & 116 & 0.39 & 46 & 5.05 & 0.051 \\
$\mathrm{LiCl}$ & 750 & 0.81 & 67 & 0.17 & 21 & 5.0 & 0.071 \\
$3 \mathrm{LiCl}-2 \mathrm{KCl}$ & 750 & 0.78 & 28 & 0.10 & 13 & n.d. & 0.036 \\
$\mathrm{NaCl}-\mathrm{KCl}$ & 750 & 0.92 & 80 & 0.06 & 7 & n.d. & 0.027 \\
\hline
\end{tabular}

n.d.: not determined

Measurements of the electrode potentials in $\mathrm{NaCl}-2 \mathrm{CsCl}$ and $\mathrm{NaCl}-\mathrm{KCl}$ melts showed that by the end of the experiments the system had reached equilibrium. On the other hand, the data in Table 2 indicate that the average oxidation state of uranium in the melt was below 6 and in some experiments the final melts contained essentially only uranyl(V) species. This means that in the melt at equilibrium with uranium dioxide some uranyl( $(\mathrm{V})$ ions are present. As the total uranium concentration in the melt decreases, the ratio of uranyl(V)-to-uranyl(VI) concentrations in the melt increases, and at the low uranium content the melt equilibrated with uranium dioxide would contain essentially only uranyl(V) ions.

\section{Zirconium and niobium}

Apart from being the most electronegative metals tested in the present study, niobium and zirconium have a very high affinity for oxygen. We had previously demonstrated that uranyl(VI) species are unstable in chloride melts in the presence of beryllium(II) ions, with uranium(IV) chloride, beryllium oxide, and chlorine being formed [21].

Upon addition of a piece of metallic niobium into the $\mathrm{NaCl}-2 \mathrm{CsCl}+\mathrm{UO}_{2} \mathrm{Cl}_{2}$ melt at $550{ }^{\circ} \mathrm{C}$ the absorbance in the visible region quickly increased. The spectra contained the two pronounced absorption bands of the uranyl(V) complex $\mathrm{UO}_{2} \mathrm{Cl}_{4}{ }^{3-}$ overlaying a broad absorption spectrum at $500-750 \mathrm{~nm}$, Fig. 10. The latter absorption is attributed to a niobium(III) and (IV) chloro-species that exist in chloride melts as octahedrally coordinated complexes $\mathrm{NbCl}_{6}{ }^{3-}$ and $\mathrm{NbCl}_{6}{ }^{2-}$, respectively [22]. The absorption bands of niobium chloro-species in the visible region in chloride melts originate from the spin allowed ${ }^{2} \mathrm{~T}_{2 \mathrm{~g}} \rightarrow{ }^{2} \mathrm{E}_{\mathrm{g}}$, for $\mathrm{Nb}(\mathrm{IV})$, and ${ }^{3} \mathrm{~T}_{1 \mathrm{~g}} \rightarrow{ }^{3} \mathrm{~T}_{2 \mathrm{~g}}$ and ${ }^{3} \mathrm{~T}_{1 \mathrm{~g}} \rightarrow{ }^{3} \mathrm{~T}_{1 \mathrm{~g}}(\mathrm{P})$, for $\mathrm{Nb}(\mathrm{III})$, transitions. After $30 \mathrm{~min}$, the absorption in the visible region began to decrease and after $2 \mathrm{~h}$ the spectrum included the absorption bands of the uranium(IV) chloride complex, $\mathrm{UCl}_{6}{ }^{2-}$, and uranyl(V) ions, $\mathrm{UO}_{2} \mathrm{Cl}_{4}{ }^{3-}$. The melt color was green (characteristic of U(IV)), and a black precipitate had formed. Its analysis showed this precipitate contained uranium and niobium, probably a mixture of uranium and niobium oxides. A 

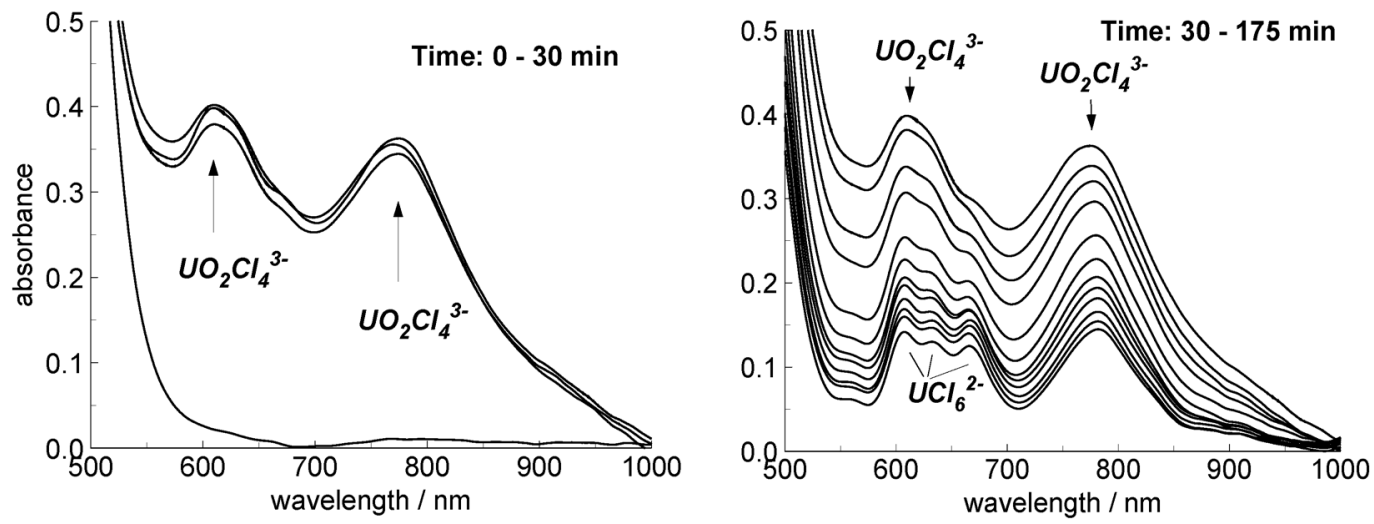

Fig. 10 Spectra recorded after contacting metallic niobium with a $\mathrm{NaCl}-2 \mathrm{CsCl}$ melt containing added $\mathrm{UO}_{2} \mathrm{Cl}_{2}$ at $550{ }^{\circ} \mathrm{C}$. Upward and downward arrows show, respectively, which species are increasing or decreasing in concentration with time.

small amount of the solid phase formed did not allow structural analysis to be performed. From common niobium oxides, formation of $\mathrm{NbO}_{2}$ and $\mathrm{Nb}_{2} \mathrm{O}_{5}$ is thermodynamically possible (for $\mathrm{NbO}$, the $\Delta G$ of the reaction is far too positive). Niobium(V) oxide is white, and microscopic examination of the solid particles did not reveal any white or gray inclusions. At the present stage it was assumed that the precipitate consisted of uranium and niobium dioxides (both black). After $175 \mathrm{~min}$, the oxidation state of uranium had dropped to 5.16 and the melt now contained $\mathrm{UO}_{2} \mathrm{Cl}_{4}{ }^{2-}, \mathrm{UO}_{2} \mathrm{Cl}_{4}{ }^{3-}, \mathrm{UCl}_{6}{ }^{2-}$, solid $\mathrm{UO}_{2}$, and $\mathrm{NbO}_{2}$. The niobium concentration in the final melt was $0.002 \mathrm{wt} \%$, so essentially all the niobium was converted to $\mathrm{NbO}_{2}$ and the absorption of the final melt was due only to $\mathrm{UO}_{2} \mathrm{Cl}_{4}{ }^{2-}, \mathrm{UO}_{2} \mathrm{Cl}_{4}{ }^{3-}$, and $\mathrm{UCl}_{6}{ }^{2-}$ species. Increasing the temperature to $750{ }^{\circ} \mathrm{C}$ for the $\mathrm{NaCl}-2 \mathrm{CsCl}$-based melt resulted in an increased reaction rate. The results are given in Table 4.

Table 4 Reaction of uranyl(VI)-containing melts with metallic $\mathrm{Nb}$.

\begin{tabular}{lccccccc}
\hline $\begin{array}{l}\text { Melt } \\
\text { composition }\end{array}$ & $T,{ }^{\circ} \mathrm{C}$ & $\begin{array}{c}\mathrm{U}(\mathrm{VI}) \text { initial } \\
\text { conc., wt.\% }\end{array}$ & $\begin{array}{c}\text { Time, } \\
\text { min }\end{array}$ & $\begin{array}{c}\text { U final } \\
\text { conc., wt.\% }\end{array}$ & $\begin{array}{c}\text { Fraction of } \\
\text { U remained } \\
\text { in the melt, \% }\end{array}$ & $\begin{array}{c}\text { Final U } \\
\text { oxidation state }\end{array}$ & $\begin{array}{c}\text { Final Nb } \\
\text { conc., wt.\% }\end{array}$ \\
\hline $\mathrm{NaCl}-2 \mathrm{CsCl}$ & 550 & 0.96 & 175 & 0.41 & 43 & 5.16 & 0.003 \\
& 750 & 0.82 & 65 & 0.33 & 40 & 5.55 & 0.005 \\
$3 \mathrm{LiCl}-2 \mathrm{KCl}$ & 750 & 0.87 & 147 & 0.13 & 45 & 3.63 & 0.004 \\
$\mathrm{NaCl}-\mathrm{KCl}$ & 750 & 0.76 & 167 & 0.31 & 41 & 3.13 & 0.006 \\
\hline
\end{tabular}

Addition of metallic niobium into a uranyl(VI) containing melt can result in a number of chemical reactions:

$$
\begin{aligned}
& 4 \mathrm{UO}_{2} \mathrm{Cl}_{4}{ }^{2-}+\mathrm{Nb}+6 \mathrm{Cl}^{-} \rightarrow 4 \mathrm{UO}_{2} \mathrm{Cl}_{4}{ }^{3-}+\mathrm{NbCl}_{6}{ }^{2-} \\
& 4 \mathrm{UO}_{2} \mathrm{Cl}_{4}{ }^{3-}+\mathrm{Nb} \rightarrow \mathrm{UCl}_{6}{ }^{2-}+\mathrm{NbO}_{2}+3 \mathrm{UO}_{2}+10 \mathrm{Cl}^{-} \\
& \mathrm{UO}_{2} \mathrm{Cl}_{4}{ }^{2-}+\mathrm{NbCl}_{6}{ }^{2-} \rightarrow \mathrm{UCl}_{6}{ }^{2-}+\mathrm{NbO}_{2}+2 \mathrm{Cl}^{-}+\mathrm{Cl}_{2} \\
& 4 \mathrm{UCl}_{6}{ }^{2-}+\mathrm{Nb}+6 \mathrm{Cl}^{-} \rightarrow 4 \mathrm{UCl}_{6}^{3-}+\mathrm{NbCl}_{6}{ }^{2-} \\
& \mathrm{UO}_{2} \mathrm{Cl}_{4}{ }^{2-}+2 \mathrm{UCl}_{6}{ }^{3-} \rightarrow 2 \mathrm{UCl}_{6}^{2-}+\mathrm{UO}_{2}+4 \mathrm{Cl}^{-} \\
& \mathrm{NbCl}_{6}{ }^{2-}+\mathrm{UO}_{2} \rightarrow \mathrm{NbO}_{2}+\mathrm{UCl}_{6}{ }^{2-}
\end{aligned}
$$


In experiments performed in $\mathrm{NaCl}-2 \mathrm{CsCl}$ eutectic the average oxidation state of uranium in the final melt was above 5. No uranium(III) ions were observed. It is argued that the niobium metal surface was passivated by an oxide layer, preventing reaction (reaction 11).

Reaction of niobium with uranyl(VI)-containing melts based on $\mathrm{NaCl}-\mathrm{KCl}$ and $3 \mathrm{LiCl}-2 \mathrm{KCl}$ mixtures at $750{ }^{\circ} \mathrm{C}$ also initially led to the formation of $\mathrm{UO}_{2} \mathrm{Cl}_{4}{ }^{3-}$ and $\mathrm{UCl}_{6}{ }^{2-}$ ions. However, after $3 \mathrm{~h}$ the melt color became red and the oxidation state of uranium was below 4, thus indicating that reaction 11 was here partially taking place.

To check the reducing ability of niobium ions toward uranyl(VI) species, a series of experiments was performed in which a sample of a $\mathrm{UO}_{2} \mathrm{Cl}_{2}$-containing melt was added to a $\mathrm{NaCl}-2 \mathrm{CsCl}$ melt containing the products of anodic dissolution of metallic niobium (a mixture of $\mathrm{NbCl}_{6}{ }^{3-}$ and $\mathrm{NbCl}_{6}{ }^{2-} \mathrm{ac}-$ cording to the spectra). The initial concentration of niobium was $0.06-0.11 \mathrm{wt} \%$ and that of uranium $0.5-0.8 \mathrm{wt} \%$. The reaction at $550{ }^{\circ} \mathrm{C}$ was very fast, and in less than $10 \mathrm{~min}$ the absorption bands of the uranium(IV) chloro-complex, $\mathrm{UCl}_{6}{ }^{2-}$, were clearly seen in the spectra. After $10-70 \mathrm{~min}$, some $\mathrm{UO}_{2}$ and $\mathrm{NbO}_{2}$ were precipitated and the melt contained uranium(IV, V, and VI) ions. The uranium content of the melt decreased by $17-24 \%$, and the final niobium concentration did not exceed $0.015 \mathrm{wt} \%$.

Another series of experiments was performed to check the possible occurrence of the following reaction in $\mathrm{NaCl}-2 \mathrm{CsCl}$ melt at $550{ }^{\circ} \mathrm{C}$ :

$$
\mathrm{NbCl}_{6}{ }^{-}+\mathrm{UO}_{2} \mathrm{Cl}_{4}{ }^{2-} \rightarrow \mathrm{NbO}_{2}+\mathrm{UCl}_{6}{ }^{2-}+{ }_{3}^{3}{ }_{2} \mathrm{Cl}_{2}+\mathrm{Cl}^{-}
$$

A sample of quenched $\mathrm{NaCl}-2 \mathrm{CsCl}+\mathrm{UO}_{2} \mathrm{Cl}_{2}$ melt was added to a melt containing $\mathrm{NbCl}_{5}$. $\mathrm{No}$ changes in the spectra were observed even after $3.5 \mathrm{~h}$, and the oxidation state of uranium in the final melt was just below six (due to some thermal decomposition of uranyl(VI) chloride). Thus, we can conclude that under the conditions studied uranium(VI) and niobium(V) chloro-species can coexist in a chloride melt.

Zirconium is electrochemically more electronegative than niobium. Addition of metallic zirconium directly into the $\mathrm{NaCl}-2 \mathrm{CsCl}$ eutectic melt containing uranyl(VI), at 550 and $750{ }^{\circ} \mathrm{C}$, produced a similar effect to that of niobium addition. Initially, the absorbance in the visible region increased and the spectra contained bands due to $\mathrm{UO}_{2} \mathrm{Cl}_{4}{ }^{3-}$ ions formed. Then (after $60 \mathrm{~min}$ at $550{ }^{\circ} \mathrm{C}$ and after $11 \mathrm{~min}$ at $750{ }^{\circ} \mathrm{C}$ ) the absorbance started to decrease and peaks associated with $\mathrm{UCl}_{6}{ }^{2-}$ appeared. After around $3 \mathrm{~h}$ of contacting zirconium with the melt, the average oxidation state of uranium decreased to 5.5, Table 5, and the final green melt contained $\mathrm{UO}_{2} \mathrm{Cl}_{6}{ }^{2-}, \mathrm{UO}_{2} \mathrm{Cl}_{6}{ }^{3-}$, and $\mathrm{UCl}_{6}{ }^{2-}$ ions and solid $\mathrm{UO}_{2}$ and $\mathrm{ZrO}_{2}$ (octahedral coordination of zirconium(IV) in chloride melts has been previously shown by EXAFS spectroscopy measurements [23]):

$$
\begin{aligned}
& 4 \mathrm{UO}_{2} \mathrm{Cl}_{4}{ }^{2-}+\mathrm{Zr}+6 \mathrm{Cl}^{-} \rightarrow 4 \mathrm{UO}_{2} \mathrm{Cl}_{4}{ }^{3-}+\mathrm{ZrCl}_{6}{ }^{2-} \\
& 4 \mathrm{UO}_{2} \mathrm{Cl}_{4}{ }^{3-}+\mathrm{Zr} \rightarrow \mathrm{UCl}_{6}{ }^{2-}+\mathrm{ZrO}_{2}+3 \mathrm{UO}_{2}+10 \mathrm{Cl}^{-}
\end{aligned}
$$

The fraction of uranium remaining in the melt decreased with increasing temperature.

Table 5 Reaction of uranyl(VI)-containing melts with metallic Zr.

\begin{tabular}{lccccccc}
\hline $\begin{array}{l}\text { Melt } \\
\text { composition }\end{array}$ & $T,{ }^{\circ} \mathrm{C}$ & $\begin{array}{c}\text { U(VI) initial } \\
\text { conc., wt.\% }\end{array}$ & $\begin{array}{c}\text { Time, } \\
\text { min }\end{array}$ & $\begin{array}{c}\text { U final } \\
\text { conc., wt.\% }\end{array}$ & $\begin{array}{c}\text { Fraction of } \\
\text { U remained } \\
\text { in the melt, \% }\end{array}$ & $\begin{array}{c}\text { Final U } \\
\text { oxidation state }\end{array}$ & $\begin{array}{c}\text { Final Nb } \\
\text { conc., wt.\% }\end{array}$ \\
\hline $\mathrm{NaCl}-2 \mathrm{CsCl}$ & 550 & 0.93 & 185 & 0.57 & 61 & 5.51 & n.d. \\
& 750 & 0.84 & 180 & 0.18 & 21 & 5.50 & 0.002 \\
$3 \mathrm{LiCl}-2 \mathrm{KCl}$ & 750 & 0.77 & 146 & 0.07 & 9 & n.d. & 0.004 \\
$\mathrm{NaCl}-\mathrm{KCl}$ & 750 & 0.72 & 180 & 0.04 & 6 & n.d. & n.d. \\
\hline
\end{tabular}

n.d.: not determined 
Similar experiments were performed in $\mathrm{NaCl}-\mathrm{KCl}$ and $3 \mathrm{LiCl}-2 \mathrm{KCl}$ melts at $750{ }^{\circ} \mathrm{C}$, Table 5 . After $3 \mathrm{~h}$ of contacting zirconium with the melt, less than $10 \%$ of uranium remained in soluble form. Absorption spectra on using the $\mathrm{NaCl}-\mathrm{KCl}$ melt contained very weak bands of $\mathrm{UCl}_{6}{ }^{2-}$, and the spectra of using the $3 \mathrm{LiCl}-2 \mathrm{KCl}$-based melt contained none. Thus, the amount of $\mathrm{UCl}_{6}{ }^{2-}$ ions formed in the melt can be associated with a decrease in the average cationic radius of the melt. The fraction of uranium remaining in the melt also decreased from ca. $21 \%$ in $\mathrm{NaCl}-2 \mathrm{CsCl}$ to ca. $6 \%$ in the $3 \mathrm{LiCl}-2 \mathrm{KCl}$ melt.

Again, although metallic zirconium should reduce U(IV) to U(III), no such reaction was observed, perhaps due to an oxide layer formed on the $\mathrm{Zr}$ surface.

The compatibility of $\mathrm{ZrCl}_{6}{ }^{2-}$ with $\mathrm{UO}_{2} \mathrm{Cl}_{4}{ }^{2-}$ was studied in $\mathrm{NaCl}-2 \mathrm{CsCl}$ at $550{ }^{\circ} \mathrm{C}$ and $\mathrm{NaCl}-\mathrm{KCl}$ at 750 and $850{ }^{\circ} \mathrm{C}$. No reaction between these species was observed at initial concentrations of uranium(VI) around $0.8-1.1 \mathrm{wt} \%$ and zirconium up to $10 \mathrm{wt} \%$. After $2-3 \mathrm{~h}$, essentially all uranium (over $93 \%$ ) remained in the melt and the average oxidation state of uranium in the final melts was $5.90-5.96$.

\section{Hydrogen reduction of uranyl(VI) containing melts}

The reaction of hydrogen with uranyl(VI)-containing alkali chloride melts leads to the ultimate precipitation of uranium in the form of $\mathrm{UO}_{2}$, and this was patented as a possible mean of reprocessing spent oxide fuels [24]. The mechanism of the reaction was not, however, studied. Here we applied high-temperature spectroscopy to follow the reaction in $3 \mathrm{LiCl}-2 \mathrm{KCl}$ (at $550{ }^{\circ} \mathrm{C}$ ), $\mathrm{NaCl}-\mathrm{KCl}$ (at $750{ }^{\circ} \mathrm{C}$ ), and $\mathrm{NaCl}-2 \mathrm{CsCl}$ melts (at 550 and $750{ }^{\circ} \mathrm{C}$ ). The behavior observed in all the systems investigated was similar. After hydrogen was bubbled through the melt, $\mathrm{U}(\mathrm{V})$ species were formed and their concentration initially increased, Fig. 11. Concentration of uranyl(V) reached maximum after several minutes (4 to 15, depending on the melt and temperature) and then began to decrease, Fig 11. At the same time, precipitation of uranium dioxide commenced. From 50 to $90 \mathrm{~min}$ (depending on the reaction conditions) were required for complete removal of uranium from the melt. The results of the experiments are summarized in Table 6, and Fig. 12 shows how the relative concentration of $U(V)$ in various melts changed over time.

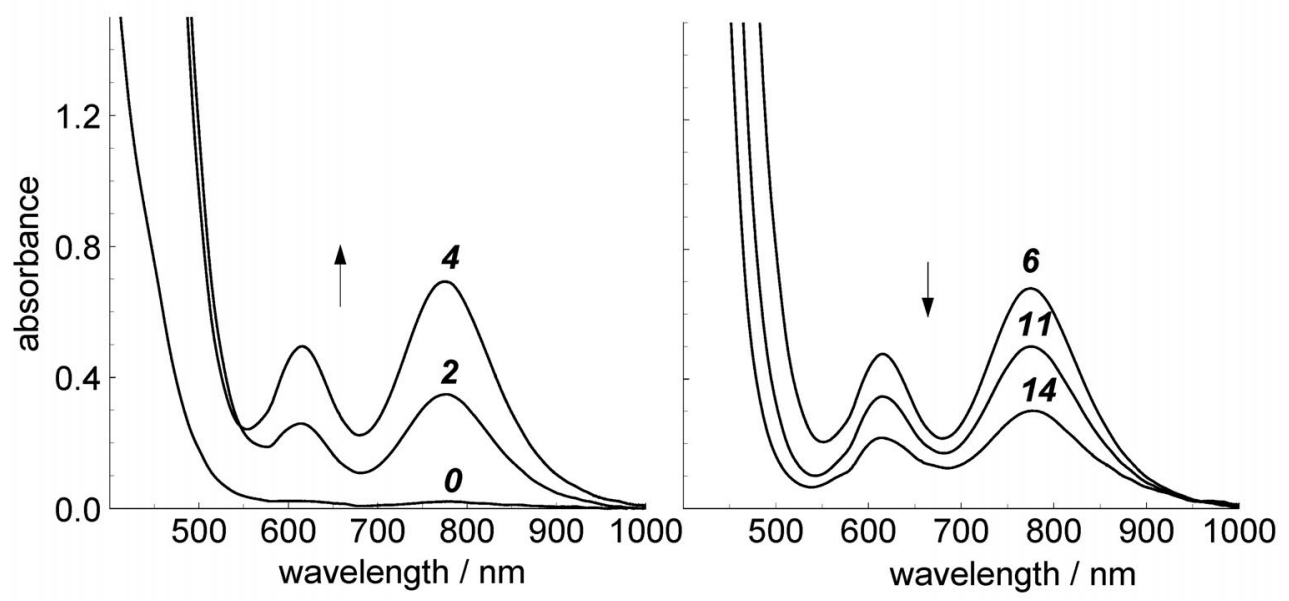

Fig. 11 Spectra recorded during reaction of hydrogen with the $\mathrm{NaCl}-2 \mathrm{CsCl}$ melt containing uranyl(VI) chloride at $750{ }^{\circ} \mathrm{C}$. Arrows show direction the peaks changed with time. Total time (in min) of bubbling hydrogen through the melt is shown on each spectrum. Initial uranium concentration $0.74 \mathrm{wt} \%$. 
Table 6 Reaction of uranyl(VI)-containing melts with $\mathrm{H}_{2}$.

\begin{tabular}{|c|c|c|c|c|c|c|c|}
\hline $\begin{array}{l}\text { Melt } \\
\text { composition }\end{array}$ & $T,{ }^{\circ} \mathrm{C}$ & $\begin{array}{l}\text { U(VI) initial } \\
\text { conc., wt. } \%\end{array}$ & $\begin{array}{c}\text { Time, } \\
\min \end{array}$ & $\begin{array}{c}\mathrm{U} \text { final } \\
\text { conc., wt. } \%\end{array}$ & $\begin{array}{c}\text { Fraction of } \\
\text { U remained } \\
\text { in the melt, \% }\end{array}$ & $\begin{array}{c}\text { Final U } \\
\text { oxidation state }\end{array}$ & $\begin{array}{l}\text { Time of } \\
\text { reaching } \\
\text { max. U(V) } \\
\text { conc., min }\end{array}$ \\
\hline \multirow[t]{4}{*}{$\mathrm{NaCl}-2 \mathrm{CsCl}$} & 550 & 0.76 & 23 & 0.62 & 82 & 5.41 & 15 \\
\hline & 550 & 0.83 & 45 & 0 & 0 & - & 9 \\
\hline & 750 & 0.74 & 48 & 0 & 0 & - & 4 \\
\hline & 750 & 0.71 & 86 & 0 & 0 & - & 5 \\
\hline $3 \mathrm{LiCl}-2 \mathrm{KCl}$ & 550 & 0.71 & 44 & 0 & 0 & - & 11 \\
\hline $\mathrm{NaCl}-\mathrm{KCl}$ & 750 & 0.42 & 56 & 0.014 & 3 & 5.62 & 7 \\
\hline
\end{tabular}

$550^{\circ} \mathrm{C}$

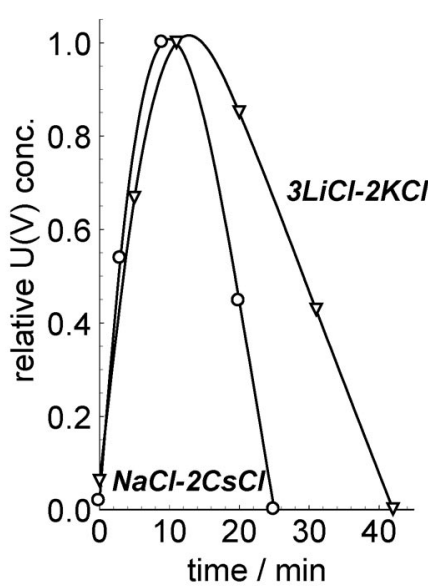

$750{ }^{\circ} \mathrm{C}$

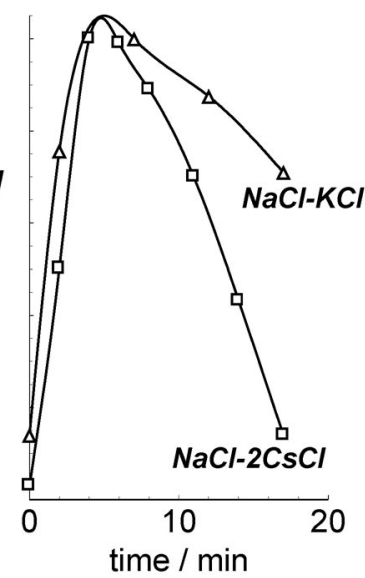

Fig. 12 Changes in relative $\mathrm{U}(\mathrm{V})$ concentration during reduction of $\mathrm{UO}_{2} \mathrm{Cl}_{4}{ }^{2-}$ by $\mathrm{H}_{2}$ over time. Temperatures and melt compositions are given for each set of data.

Reaction of uranyl(VI) chloride with hydrogen in chloride melts therefore proceeds in two stages:

$$
\begin{aligned}
& \mathrm{UO}_{2} \mathrm{Cl}_{4}{ }^{2-}+1 / 2 \mathrm{H}_{2}+\mathrm{Cl}^{-} \rightarrow \mathrm{UO}_{2} \mathrm{Cl}_{4}{ }^{3-}+\mathrm{HCl} \\
& \mathrm{UO}_{2} \mathrm{Cl}_{4}{ }^{3-}+1 / 2 \mathrm{H}_{2} \rightarrow \mathrm{UO}_{2}+\mathrm{HCl}+3 \mathrm{Cl}^{-}
\end{aligned}
$$

Thermodynamic calculations show that, for example, in molten $\mathrm{NaCl}-2 \mathrm{CsCl}$ at a total uranium concentration around $0.7 \mathrm{wt} \% \Delta G_{(17)}$ will become equal to $\Delta G_{(18)}$ when the average oxidation state of uranium in the melt decreases to ca. 5.67 (at $550{ }^{\circ} \mathrm{C}$ ) or to ca. 5.45 (at $750{ }^{\circ} \mathrm{C}$ ), showing that around half of the uranium(VI) can be reduced to $\mathrm{U}(\mathrm{V})$ before reduction to $\mathrm{UO}_{2}$ commences.

In one of the experiments performed in the $\mathrm{NaCl}-2 \mathrm{CsCl}$ melt at $750{ }^{\circ} \mathrm{C}$, the absorption spectra recorded were different from the rest. Initially, the bubbling of hydrogen resulted in the typical absorption of $\mathrm{UO}_{2} \mathrm{Cl}_{4}{ }^{3-}$; the concentration of this species initially increased and then started to decrease. After 15 min reduction the melt was dark red and the spectral profile had changed, Fig. 13. The absorption around $780 \mathrm{~nm}$ decreased but rose significantly at wavelengths below $680 \mathrm{~nm}$, and the spectra exhibited three well-pronounced maxima between 360 and $600 \mathrm{~nm}$. The concentration of this new uranium species in the melt initially increased and then began to decrease until all the uranium was removed from the melt after $44 \mathrm{~min}$ of hydrogen reduction. Attempts to reproduce this phenomenon were not successful. At present, it is difficult to characterize unambiguously that a new uranium species formed. 


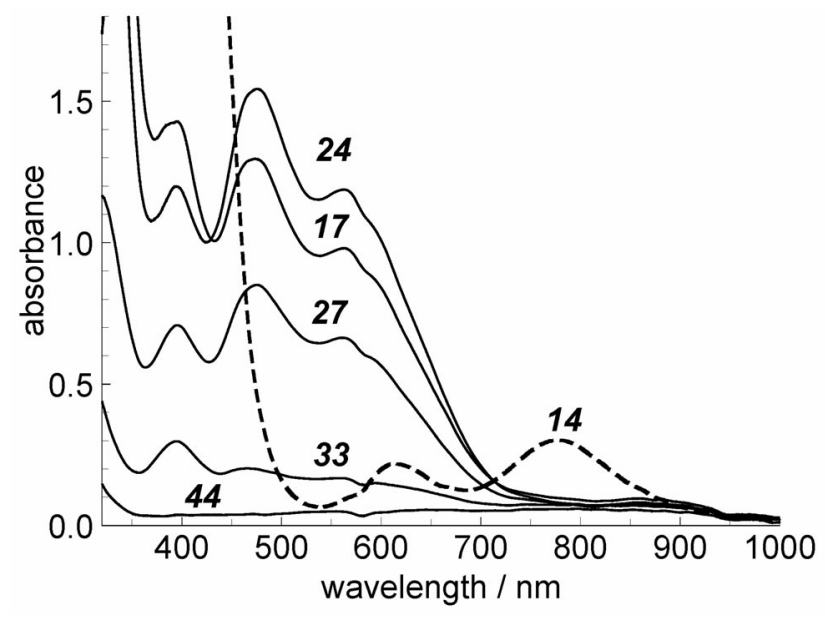

Fig. 13 Spectra recorded during reaction of hydrogen with $\mathrm{NaCl}-2 \mathrm{CsCl}$ melt containing uranyl chloride at $750{ }^{\circ} \mathrm{C}$. Total time (in min) of bubbling hydrogen through the melt is given for each spectrum. Initial spectrum (14 min) is the same as in Fig. 11.

The spectra observed, however, are very similar to the absorption spectrum of $\mathrm{UOCl}_{3}$ (reported in a petroleum mull [4]). It is therefore possible that the monooxouranium(V) chloro-species may be formed under certain conditions in chloride melts according to one of the following reactions:

$$
\begin{aligned}
& 3 \mathrm{UO}_{2} \mathrm{Cl}_{4}{ }^{3-}+\mathrm{H}_{2} \rightarrow \mathrm{UOCl}_{5}{ }^{2-}+2 \mathrm{UO}_{2}+\mathrm{H}_{2} \mathrm{O}+7 \mathrm{Cl}^{-} \\
& 2 \mathrm{UO}_{2} \mathrm{Cl}_{4}{ }^{2-}+\mathrm{H}_{2}+\mathrm{Cl}^{-} \rightarrow \mathrm{UOCl}_{5}{ }^{2-}+\mathrm{UO}_{2} \mathrm{Cl}_{4}{ }^{3-}+\mathrm{H}_{2} \mathrm{O}
\end{aligned}
$$

\section{CONCLUSIONS}

In the present work, the reactions leading to the formation of uranyl(V) chloro-species in uranyl(VI)containing melts were studied between 550 and $850{ }^{\circ} \mathrm{C}$. Decomposition of uranyl(VI) species by heating the starting melt under vacuum, bubbling an inert gas through the melt, or by removing $\mathrm{Cl}_{2}$ from the atmosphere above the melt using a suitable getter resulted in partial conversion of U(VI) ions to $\mathrm{U}(\mathrm{V})$ ions and $\mathrm{UO}_{2}$. The degree of $\mathrm{UO}_{2} \mathrm{Cl}_{4}{ }^{2-}$ decomposition increased with temperature and also with decreasing the alkali cation radius of the salt solvent. No soluble U(IV) species were detected.

Contacting metallic tellurium, palladium, silver, molybdenum, niobium, and zirconium with alkali chloride melts containing uranyl(VI) chloride leads to its reduction to uranyl(V) chloride and uranium dioxide. The outcome of the reaction depends on the electrochemical properties of the reductant; the more electronegative the metal the higher the degree of $\mathrm{U}(\mathrm{VI})$ reduction. In the case of niobium and zirconium, some uranium(IV) chloride was also formed due to the high affinity of niobium and zirconium ions for oxygen.

A detailed study of the reaction of uranyl(VI)-containing melts with molybdenum showed that the degree of $\mathrm{U}(\mathrm{VI})$ conversion to $\mathrm{UO}_{2}$ increases from $\mathrm{NaCl}-2 \mathrm{CsCl}$ to $\mathrm{LiCl}$ melt. Results obtained in $\mathrm{NaCl}-\mathrm{KCl}$ and $\mathrm{NaCl}-2 \mathrm{CsCl}$-based melts indicated that the melts in equilibrium with uranium dioxide contain a mixture of uranyl(VI) and (V) species or, at low uranium concentrations, essentially only uranyl(V) ions.

Bubbling hydrogen through a uranyl(VI)-containing melt resulted in a two-stage reduction $\mathrm{U}(\mathrm{VI}) \rightarrow \mathrm{U}(\mathrm{V}) \rightarrow \mathrm{UO}_{2}$. 


\section{REFERENCES}

1. L. R. Morss, N. M. Edelstein, J. Fuger, J. J. Katz (Eds.). The Chemistry of Aactinide and Transactinide Elements, $3^{\text {rd }}$ ed., Vol. 1, Springer, Dordrecht (2008).

2. (a) D. Cohen. J. Inorg. Nucl. Chem. 32, 3525 (1970); (b) D. Ferri, I. Grenthe, F. Salvotore. Inorg. Chem. 22, 3162 (1983); (c) T. I. Docrat, J. F. W. Mosselmans, J. M. Charnock, M. W. Whiteley, D. Collison, F. R. Livens, C. Jones, M. J. Edmiston. Inorg. Chem. 38, 1879 (1999); (d) A. Ikeda, C. Hennig, S. Tsushima, K. Takao, Y. Ikeda, A. C. Scheinost, G. Bernhard. Inorg. Chem. 46, 4212 (2007).

3. (a) D. C. Bradley, B. N. Chakravarti, A. K. Chatterjee. J. Inorg. Nucl. Chem. 3, 367 (1957); (b) J. L. Ryan. J. Inorg. Nucl. Chem. 33, 153 (1971); (c) P. L. Arnold, J. B. Love, P D. Patel. Coord. Chem. Rev. 253, 1973 (2009).

4. D. A. Wenz, M. D. Adams, R. K. Steunenberg. Inorg. Chem. 3, 989 (1964).

5. M. D. Adams. J. Phys. Chem. 67, 1939 (1963).

6. V. E. Komarov, N. P. Nekrasova. Radiokhimiya 25, 233 (1983) (in Russian).

7. (a) V. A. Volkovich, I. May, J. M. Charnock. Rasplavy No. 2, 76 (2004) (in Russian); (b) V. A. Volkovich, I. May, C. A. Sharrad, H. Kinoshita, I. B. Polovov, A. I. Bhatt, J. M. Charnock, T. R. Griffiths, R. G. Lewin. In Recent Advances in Actinide Science, I. May, R. Alvarez, N. D. Bryan (Eds.), pp. 485-490, Royal Society of Chemistry, London (2006).

8. D. A. Costa, W. H. Smith, H. J. Dewey. In Molten Salts XII, ECS Proceedings Series 99-41, P. C. Trulove, H. C. De Long, G. R. Stafford, S. Deki (Eds.), pp. 80-99, Electrochemical Society, Pennington (2000).

9. R. S. Wilks. J. Nucl. Mater. 7, 157 (1962).

10. R. W. Stromatt. J. Electrochem. Soc. 110, 1277 (1963).

11. M. V. Smirnov, V. E. Komarov, A. P. Koryushin. At. Energ. 22, 30 (1967) (in Russian).

12. T. Nagai, T. Fujii, O. Shirai, H. Yamana. J. Nucl. Sci. Technol. 41, 690 (2004).

13. V. A. Volkovich, I. B. Polovov, B. D. Vasin, T. R. Griffiths, C. A. Sharrad, I. May, J. M. Charnock. Z. Naturforsch., A 62, 671 (2007).

14. B. D. Vasin, S. P. Raspopin, V. A. Ivanov. In VI Kola Symp. Electrochem. Rare and Non-ferrous Metals, p. 88, KSC, Apatity (1989) (in Russian).

15. B. D. Vasin, S. V. Maslov, V. A. Volkovich, I. B. Polovov, S. A. Kazakov, O. I. Rebrin. In Proc. $7^{\text {th }}$ Int. Symp. Molten Salts Chemistry and Technology, 29 Aug.-2 Sept. 2005, Toulouse, France, Vol. 1, P. Taxil, C. Bessada, M. Cassir, M. Gaune-Escard (Eds.), pp. 335-340 (2005).

16. A. A. Khokhryakov. Radokhimiya 40, 400 (1998) (in Russian).

17. M. V. Smirnov, O. V. Skiba. Trans. Inst. Electrochem. UBAS USSR 4, 17 (1963) (in Russian).

18. (a) R. A. Bailey, J. A. McIntyre. Inorg. Chem. 5, 1824 (1966); (b) J. R. Dickinson, K. E. Johnson. Can. J. Chem. 45, 1631 (1967); (c) J. R. Dickinson, K. E. Johnson. Can. J. Chem. 45, 2457 (1967); (d) D. V. Bamburov, B. D. Vasin, A. S. Kazakov, S. P. Raspopin. Izv. Vuzov, Tsvet. Metallurgiya No. 4, 56 (1983) (in Russian).

19. (a) J. C. Gabriel, D. Vincent, J. Bouteillon, J. C. Poignet, V. A. Volkovich, T. R. Griffiths. Electrochim. Acta 44, 4619 (1999); (b) V. A. Volkovicha, T. R. Griffiths, R. C. Thied, B. Lewin. J. Nucl. Mater. 323, 93 (2003).

20. B. D. Vasin, V. A. Ivanov, I. V. Shulman, S. P. Raspopin. Izv. Vuzov, Tsvet. Metallurgiya No. 2, 68 (1987) (in Russian).

21. V. A. Volkovich, I. May, T. R. Griffiths, J. M. Charnock, A. I. Bhatt, B. Lewin. J. Nucl. Mater. 344, 100 (2005). 
22. (a) S. V. Maslov, B. D. Vasin. Rasplavy No. 3, 66 (1993) (in Russian); (b) G. A. Voyiatzis, E. A. Pavlatou, G. N. Papatheodorou, M. Bachtler, W. Freyland. In Molten Salt Chemistry and Technology, Proc. Electrochem. Soc. 93-9, M.-L. Saboungi, H. Kojima, J. Duruz, D. Shores (Eds.), pp. 252-264, Electrochemical Society, Pennington (1995); (c) C. Rosenkilde, G. Voyiatzis, V. R. Jensen, M. Ystenes, T. Ostvold. Inorg. Chem. 34, 4360 (1995).

23. (a) Y. Okamoto, H. Motohashi. Z. Naturforsch., A 57, 277 (2002); (b) V. A. Volkovich, I. May, T. R. Griffiths, J. M. Charnock, B. G. Lewin. In Molten Salts XIV, ESC Proceedings Series PV 2004-24, R. A. Mantz, P. C. Trulove, H. C. De Long, G. R. Stafford, M. Hagiwara, D. A. Costa (Eds.), pp. 162-169, Electrochemical Society, Pennington (2006).

24. A. Avogadro, V. V. Dandolo, S. Krawczynski. UK Patent 1084340, Filed 10 December 1964, Issued 20 September 1967. 